\title{
Exploring Head Teachers' Instructional Supervisory Role: The Case of Public Junior High Schools in Jirapa Municipality of Ghana
}

\author{
American Journal of Education and \\ Learning \\ Vol. 6, No. 1, 64-75, 2021 \\ e-ISSN:2518-6647 \\ $\checkmark$ updates
}

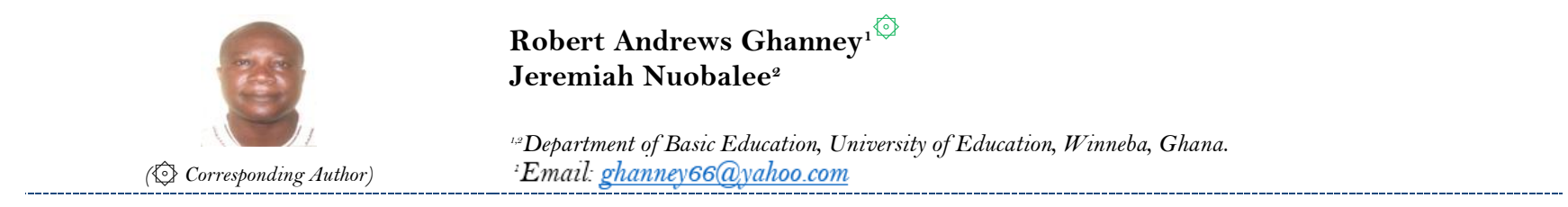

\section{ABSTRACT}

The study explored Head teachers' instructional supervisory role among public Junior High Schools in the Jirapa Municipality of the Upper West Region of Ghana. It adopted psychological and system theory of supervision propounded by Planturrroot (2006) and Bertalanffy (2015) respectively. The mixed method sequential approach was followed in the conduct of the study where both quantitative and qualitative data were collected and analysed. A sample size of 200 respondents made up of 40 head teachers, 80 teachers and 80 pupils were used for the quantitative data, whilst 10 head teachers were selected for the qualitative data. The Statistical Product for Service Solutions (SPSS) version 23 was used to analyse the quantitative data while thematic approach was used for the qualitative data. The findings of the study revealed in-frequent orientation for newly engaged teachers. It further showed lower ratings in the provision of in-service training, time tabling design and setting of performance target for pupils and teachers. It was recommended that the Ministry of Education and Ghana Education Service (GES) should regularly organize workshops, seminars and in-service trainings on supervisory roles of head teachers and assistant head teachers to equip them with the needed knowledge and skills in the municipality. Lastly, Heads of schools and other supervisors should re-design schools time tables to suit the use of instructional time in the lesson of teachers to enhance their monitoring.

Keywords: Instructional supervisory role, In-service training of teachers, Performance target for pupils, Curriculum time tabling, Academic progress of pupils, Workshops, Seminars, Heads of schools, Teachers and monitoring.

DOI: $10.20448 / 804.6 .1 .64 .75$

Citation | Robert Andrews Ghanney; Jeremiah Nuobalee (2021). Exploring Head Teachers' Instructional Supervisory Role: The Case of Public Junior High Schools in Jirapa Municipality of Ghana. American Journal of Education and Learning, 6(1): 64-75.

Copyright: This work is licensed under a Creative Commons Attribution 3.0 License

Funding: This study received no specific financial support.

Competing Interests: The authors declare that they have no competing interests.

History: Received: 16 June 2021/ Revised: 19 July 2021/ Accepted: 12 August 2021/ Published: 2 September 2021

Publisher: Online Science Publishing 


\section{Highlights of this paper}

- The paper offers a research study that explores the instructional supervisory roles of head teachers in Jirapa Municipality of Ghana through contributions from noted experts in the area.

- It highlights head teachers' instructional tasks such as orientation for new teaching staff, lesson observation, in-service training for teachers, time-tabling checking, monitoring of teachers' punctuality and regularity in class and setting of performance targets for teachers and pupils.

\section{INTRODUCTION}

Supervisors play a perversive role and support to teachers to facilitate effective decision-making in school instructional process(Glanz \& Heinmann, 2018). Yet, effort of supervisors in ensuring quality instructional competencies is constrained by lack of skills on the part of teachers (Zedepeda, 2012). Role- conflict between teachers and supervisors stems from lack of supervisory skills especially if teachers feel ill-treated (Madziyire, 2013). According to Marks (2008), heads are good at managerial roles which requires quite different skills. Effective Supervision has the potentials of enhancing effective student outcomes by way of continuous professional development of teachers (Blase \& Blasé, 2004).

According to Sapsford (2007), supervision creates space for schools to address school improvement quality issues as well as student success. Glickman, Gordon, and Ross-Gordon (2001) conception of supervision as a 'pillar' of school improvement quality issues holds true. It is the responsibility of school to bring on board all stakeholders in education to ensure effective instructional supervision (Glickman et al., 2001). According to Glickman et al. (2001), effective supervision hinges on a knowledge base, interpersonal skills, and technical skills of actors in school. In their study, Hallinger and Heck (2018) found positive correlation between checking of pupils notes and their academic progress in the United State of America (USA) elementary schools. In Asia, supervision has become a cardinal issue in matters of school operation (Sergiovanni, Starratt, \& Sullivan, 2011). A study by Sharma, Yusoff, Kannan, and Baba (2011) in Thailand, Malaysia and India showed that instructional supervision in these three Asian countries is not conducted effectively. They further added that even though head teachers and other heads are responsible for the instructional supervision, the benefit out of the process is not felt at all. Almost all teachers from these countries feel that they as well as their pupils are not at all benefitting from the instructional supervision due to the continued poor performance in examinations (Sharma et al., 2011). This indicates that in the three Asian countries, instructional supervision is not given the desired results.

Studies done in Africa within schools also show similar and different results as the ones in Asia and USA. In a study done in Nigeria by Fischer (2011), the author notes that supervision embraces all efforts of school officials geared towards realization of effective leadership to the benefits teachers and learners in the educational process. Akinola (2010) noted poor academic performance among pupils in primary and secondary schools at external examinations, however, research findings have shown difficulties in measuring accurately instructional supervision and its effects on academic performance (Leithwood, Jantzi, \& Lee, 2004). Research into school governance, indicates the effectiveness of head teachers' leadership on pupils' performance (Fullan, 2014). Ayeni, Adeolu, and Joshua (2012) in their study in Nigeria noted that majority of pupils in the country perceived their teachers' performance of instructional task based on the supervision provided by the Head teachers as very effective as this improves pupils' academic achievements in Nigeria. While a study conducted by Esia-Donkor (2014) in Ghana also observed that poor instructional supervision in public schools has also resulted in poor academic achievements among the pupils. Planturrroot (2006) framework of the system theory of structures endorsed by biologist Bertalanffy (2015) constitutes the theoretical framework of the study. According to Planturrroot (2006), the 
organization is a body with other parts of the body working together and a head delegating tasks to other parts of the organization. This head acts as a supervisor overseeing the operation of each part of the organization. This idea is in line with our research in which the Head teacher is the instructional leader who delegates and monitors the success of the organization's teachers and students. Head teacher is normally appointed by somebody. The organizational process should be managed by someone in order for one to have a purposeful organisation. In most organisations, the boss is the overseer and also assigns roles within the organisation to others. Educational supervision in contemporary Ghana is considered as the mechanism of improving the teacher's continuous professional development (Okendu, 2012). According to Nakpodia (2006), in the contemporary age, instructional supervision focuses on assisting teachers and learners to recognize areas of teacher success and deficiencies. Instructional management, irrespective of what may be involved in either curriculum creation or personnel development, is solely obsessed with developing classroom processes for the benefits of students (Palandra, 2010). (Beach \& Reinhartz, 2000) have emphasized that educational monitoring focuses on equipping instructors with knowledge and skills about their teaching in order to assist them develop results. In the study, there is nexus among educational supervision, student learning and school improvement (Jenkins, 2009). Professional advancement progress and skill, are another aims of instructional supervision according to Nolan and Hoover (2008), and has been described as an essential part of employee performance. Zepeda (2003) also notes that the aim of supervision is to foster growth, development, engagement, analytical thinking without fault, and a dedication to teacher capacity building. The fundamental role of instructional supervision, according to Yousuf (2011), is to enhance instructional learning process, but should not be limited to only visits to the classroom and completion of logbook. It also includes the support of teachers, and professional growth. De Grauwe (2007) supports the view that the first duty of the Inspectorate Service is to ensure that schools and resources comply with the rules, legislation and all other legal requirements of the Education Administration. Similarly, in the Netherlands, maintaining compliance with legislative legislation has always been the primary responsibility of the inspectorate. Traditionally, this has been seen as an effective way to ensure that teaching and training is offered in any given industry. It appears that supervision builds and promotes the drive and devotion of teachers to teaching, the overall aims of the school, and the defining educational platform of the school. However, the accomplishment of those purposes depends on the consistency of the supervisory procedure and the efficient method of supervision. The method of promoting the professional development of teachers, the curriculum and strengthening teaching strategies depends to a very large extent on instructional supervisory role of head teachers (Okendu, 2012).

The pupils' performance at the BECE in Jirapa Municipality administered by West Africa Examination Council (WAEC) has shown persistent failure rate of 63.7, 69.6, 65.7, 70.5 and 82.5 percent in 2014, 2015, 2016, 2017, and 2018 respectively. What is more worrisome is that the BECE serves as the foundation for Senior High School (SHS) and the rate of failure is attracting lots of dissatisfied concerns among parents and stakeholders of education in the Municipality. In-spite of the Ministry of Education role in enhancing academic achievement of pupils, it appears few studies have been done on. Instructional Supervision within public basic schools and Jirapa municipality is no exception. As indicated earlier, a study by Sharma et al. (2011) in Thailand, Malaysia and India revealed that head teachers are responsible for the instructional supervision, but the benefit out of the process is not felt at all. In the case of Ghana, most of the studies on instructional supervisory role have been done in the southern part of Ghana. For instance, Kusi and Mensah (2014) conducted a study on head teachers' supervisory styles in the Volta region. Also, Esia-Donkor and Baffoe (2018) research was on head teachers' instructional supervisory practices and teacher motivation in educational circuit of Anomabo in Central region of Ghana. However, literature is virtually silent on this study in the Northern part of Ghana, particularly in Jirapa Municipality of the Upper West Region of Ghana. 
Head teachers in Ghana are expected to perform instructional tasks such as lesson observation, orientation of new staff, monitoring punctuality and regularity of teachers, checking school records and conducting in-service training (Esia-Donkor \& Baffoe, 2018). It is not clear what instructional supervisory roles head teachers in Jirapa municipality perform considering poor academic performance of pupils at BECE in recent times. Hence, this study explored head teachers' instructional supervisory roles in Jirapa Municipality of the Upper West Region of Ghana.

Theoretically, it is anticipated that the study's outcomes would help in obtaining contextual data to shed more light on the public Junior High School head teachers' instructional supervisory role in the Jirapa municipality. Practically, it is hoped that the findings would be significant to various stakeholders with regard to the research. The outcome of this particular research serves great value and importance to pupils, head teachers, circuit supervisors, district monitoring personnel and other practioners in the field of education to adopt the acceptable supervisory measures that would enhance effective academic performance of the basic education in Ghana. The results of the research would be of help to heads of institutions, the Ghana Education Services (G.E.S) and the Ministry of Education as important information needed for policy direction relative to circuit supervision. Individuals and organizations who are interested in improving the quality of education such as school boards, Churches, Alumni Associations, School Management Committees (SMC), Parent Teacher Association (P.T.A), National Council for Curriculum and Assessment (NaCCA), Non-governmental Organization (NGO), District Assemblies and Community groups may be guided by the findings of this study. The study would also help improve and update existing literature on school supervision while laying bare other information for implementation and development of effective mechanism for supervisors in the Public Basic Schools level. Finally, this study would inspire other researchers to embark on similar studies into the JHS head teachers' role at the public basic schools in other districts, metropolitans and municipalities. The following research questions guided the study RQ 1: What supervisory roles head teachers in public basic JHS perform in Jirapa Municipality of Ghana? RQ 2: What are the pupils' views on their head teachers' supervisory roles in the Jirapa Municipality of Ghana?

\section{METHODOLOGY}

In this study, the mixed method research methodology was utilized. The approach to mixed approaches is based on the premise that both strategies are characterized with biases and limitations and the use of quantitative and qualitative data stabilizes each type of data (Creswell, 2014). The researchers used the mixed method approach of both quantitative and qualitative methods to collect and interpret the data in order to eliminate these biases.

Sequential Explanatory design of mixed methods was used. It is a mixed approach technique involving a twostep process in which, in the first phase, quantitative data are analysed and findings employed to prepare (or develop into) the second, qualitative phase (Creswell, 2014). In this study, a quantitative data made up of 40 head teachers, 80 teachers and 80 pupils were collected and analysed in the first phase and utilised to prepare the qualitative data of 10 head teachers in the second phass.

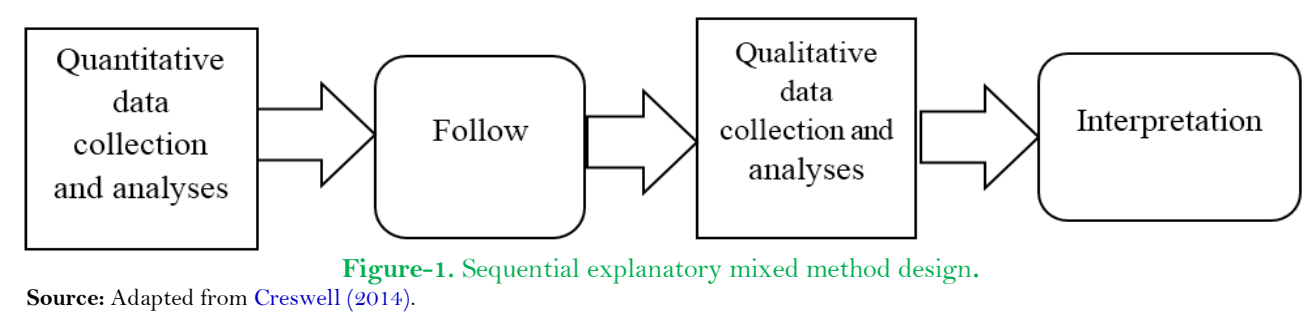


The study was conducted in Jirapa Municipality. It shares borders with the Municipality of Lawra in the West, the District of Nadowli in the South, the District of Lambusie-Karni in the North East, and Sissala East in the East. With agriculture as its main occupation, Jirapa is the capital city of the municipality. This place was chosen because one of the researchers has been living there for over thirty years and has been a teacher there for the past sixteen years, making him have an in-depth history of the place. In the research, head teachers, teachers, and pupils were used because they are the main implementers of the curriculum that emphasizes supervisory roles of head teachers.

Since the study centered on the head teachers' instructional supervisory roles, the population for this study comprised all Junior High School head teachers, teachers and pupils in the Jirapa Municipality. The target population was all Junior High School Head Teachers, teacher and pupils' leaders (boys' and Girls' senior prefect) in the Jirapa Municipality of Ghana. The sample size was two hundred (200) participants comprising JHS head teachers, teachers as well as pupils' leaders.

The Sampling technique employed in collecting data about the JHS in the Municipality was Census. A census is suitable for small populations (e.g., 200 or less), according to Glenn (2012), thereby reducing sampling error and providing a true measure of data on all individuals in the sample. A convenience sampling technique was used to select ten (10) JHS head teachers in the qualitative data. The ten (10) JHS head teachers sampled for the qualitative aspect is in line with Boyd (2001) who opines that two (2) to ten (10) participants will be able to produce saturated data in any qualitative work. This view is also supported by Morse (1994) who asserted that at least six (6) participants are enough to produce saturated data, in affirming this, Creswell (2014) recommends between five (5) to twenty-five (25) respondents in qualitative study hence the choice of the ten respondents for the qualitative data collection was in line with the views expressed by these authorities. To assure anonymity, the ten (10) head teachers were identified as head teachers one (Htr. 1), head teachers two (Htr. 2) up to head teachers ten (Htr. 10) that was solely for the qualitative aspect. The teachers were stratified and selected using simple random techniques. Two pupils' leaders were also purposively sampled from each school for the study. This included identifying and selecting respondents or participants well informed and knowledgeable about a phenomenon of interest (Creswell \& Plano, 2011).

The questionnaires were given to teachers, head teachers as well as students under the basis that the language could be understood. The closed-ended questionnaire items measured on a four Likert- point scale, gives the researcher the ability to achieve a higher uniformity of respondent responses to make it easier to process. In addition, respondents were given few open-ended types of items to share their thoughts, perceptions, issues and intentions relevant to school-based supervision activities. In agreement with the above concepts, Cohen, Manion, and Morrison (2017) called for more structured questionnaire containing pre-determined responses from which the respondents can only choose. The questionnaire was made up of two sections. Section one was about the demographic characteristics of the respondents. The second section focused on the head teachers' instructional supervisory roles whilst the third and last section was about head teachers and teachers' views about head teachers' supervisory roles. Forty-five (45) items were designed to collect data on the level of agreement between JHS head teachers / teachers using 4-point likert scale. In order to obtain comprehensive and in-depth data, the researchers conducted a semi-structured interviews with ten (10) head teachers of the school in order to secure information about their experience in supervisory activities/roles. To ensure validity of the items on the questionnaires, the content validity was granted by experts and peers knowledgeable in the issues of the study. The survey instrument was subjected to pre-testing prior to its distribution to the participants. Two schools in the Nadowli district were selected with participants made up of four head teachers, eight teachers as well as ten students. The researchers chose this District because it was one of the districts which exhibited the same characteristics as those of Jirapa 
Municipality. In testing for reliability of the instrument, re-set method was employed. According to Gelman and Hill (2007) the instrument should be tested at two different times to check for computation of correlation between the two sets of scores. The piloting was done twice. Piloting the questionnaires twice was to make the instruments accurate as possible.

Lincoln and Guba (2015) used alternative terms for qualitative research which are credibility, transferability, dependability, and conformability and these were followed to make sure that the qualitative instruments for data collection were valid and reliable. The researchers reported to the Municipal Education Director of Education, Jirapa to obtain permission to undertake the research in the selected schools in the municipality. The researchers also made visits to the selected school heads for negotiation to be made on when and how to administer the instruments. Staff members were given brief orientation by the researchers to enable them understand the procedures for administering the questionnaire. Respondents were expected to provide candid responses and opinions based on the questionnaire which, when compiled and analyzed, provide adequate information vital for use by the researchers. Questionnaires were administered to head teachers, and teachers. Respondents were given one week ultimatum within which to complete the questionnaire after which period, the researchers went round to collect the completed questionnaires.Quantitative data was analyzed using descriptive statistics involving frequencies and percentages and the findings in tabular form. The data generated from the questionnaire were coded and entered into the version 23 Statistical Product for Service Solution (SPSS) which assisted data analysis. Qualitative data, on the other hand, was done through playing the recorded tapes several times, transcribing the tapes into texts and deriving themes from the responses of the participants. This is because according to Adu (2019), in Mixed Method, the data thus qualitative and quantitative data were analyzed separately and are merged at the interpretation stage.

\section{RESULTS AND DISCUSSION}

The distribution of respondents based on their sex, age and academic qualification is indicated in Table 1.

\begin{tabular}{ccccccc}
\multicolumn{7}{c}{ Table-1. Sex distribution of respondents. } \\
\hline Sex & Head teachers $\%$ & Teachers & $\mathbf{\%}$ & Pupils & $\mathbf{\%}$ \\
\hline Male & F & \% & F & $\mathbf{\%}$ & F & \% \\
\hline Female & 30 & 75 & 55 & 68.7 & 40 & 100 \\
\hline Total & 10 & 25 & 25 & 31.3 & 40 & 100 \\
\hline Source: Field data, 2020. & 100 & 80 & 100 & 80 & 100 \\
\hline
\end{tabular}

Table-2. Age distribution of Head teacher respondents.

\begin{tabular}{ccc}
\multicolumn{2}{c}{ Table-2. Age distribution of Head teacher respondents. } \\
\hline Age (in years) & Frequency & Percentage (\%) \\
\hline 24 and below & $\mathbf{0}$ & $\mathbf{0}$ \\
\hline $25-29$ & 6.0 & 15 \\
$30-35$ & 12 & 30 \\
$40-49$ & 20 & 50 \\
\hline 50 and above & 2 & 5.0 \\
\hline Total & 40 & 100 \\
\hline Source: Field data, 2020. & &
\end{tabular}

It can be observed from Table 1 that the respondents were predominantly male. The phenomenon of male respondents out numbering their female counterparts is not only peculiar to the teachers but could also be seen among head teachers. Among the teachers, $68.7 \%$ were males with $31.3 \%$ being female, while, the head teacher respondents were $75 \%$ and $25 \%$ male and female respectively. This implies that male head teachers in the high 
schools in Jirapa municipality outnumber that of their female counterparts. There exists no sex disparity regarding distribution of pupils unlike male and female head teachers and teachers.

Table 2 shows that, $50 \%$ of head teacher respondents were within the age bracket of 40 to 49 years, with $30 \%$ within 30 to 35 years or above and $15 \%$ within 25 to 29 years, an indication of long experienced teachers with developed supervisory leadership as stipulated in the Ghana Education Service (GES) head teachers' manual

\begin{tabular}{lcccc}
\multicolumn{2}{c}{ Table-3. Highest professional qualifications of respondents. } \\
\hline Qualification & Headteachers & \multicolumn{2}{c}{ Teachers } \\
\cline { 2 - 5 } & $\mathbf{F}$ & $\mathbf{\%}$ & $\mathbf{F}$ & $\mathbf{\%}$ \\
\hline Teachers' Certificate “A” & 0 & 0.0 & 0 & 0.0 \\
\hline Diploma in basic Education & 10 & 25.0 & 20 & 25.0 \\
\hline BA/ BSc & 25 & 62.5 & 6 & 7.5 \\
\hline B.Ed (Basic Education) & 5 & 12.5 & 50 & 62.5 \\
\hline MPhil/MA/MSC/M.ED & 0 & 0.0 & 4 & 5.0 \\
\hline PhD & 0 & 0.0 & 0 & 0.0 \\
\hline Total & 40 & 100 & 80 & 100 \\
\hline Source: Field data, 2020. & & & &
\end{tabular}

In Table 3 above, 10 (25\%) of the head teachers had diploma in basic education, while $20(25 \%)$ of teachers have diploma in basic education certificate However, there are 25(62.5\%) head teachers and 6(7.5\%) teachers who are either Bachelor of Arts (BA) or Bachelor of Science (BSC) degree holders. Meanwhile majority of the teachers 50 $(62.5 \%)$ hold Bachelor of Education (Basic Education) while 5(12.5\%) of the head teachers possessed Bachelor of Education (Basic Education). In the nutshell, there are 4(5\%) respondents with MPhil/MA/MSC/M.ED. This finding confirms claims of Glickman (2010) about the need of head teachers to possess conceptual understanding and skills to support teachers in their preparation of scheme of work and lesson plans. The finding also raises concerns about capacity of unprofessional teachers (Master degree holders) to support teachers in their instructional supervisory roles. According to Blase and Blasé (2004) in-service training equips teachers with innovative ideas about their instructional roles.

Research Question One: What supervisory roles head teachers in JHS perform in Jirapa Municipality of Ghana?

In answering this research question, views were sought from respondents in relation to head teachers' supervisory roles in the art of supervision, monitoring and evaluation; views of respondents were sought based on some statement on the head teachers' supervisory role. They were to respond to variables measured on 4-point Likert scale (strongly agree, agree, strongly disagree and disagree). In analyzing the data, strongly agreed and agreed were lumped together as agreeing (A) to a statement. Likewise, disagree and strongly disagree are also grouped together as disagreeing (DA) to a statement. The results are as indicated in Table 4.

Table-4. Head teachers' and teachers' views on supervisory roles in public JHS.

\begin{tabular}{lccccccccc}
\hline Statement & \multicolumn{3}{c}{ Head teachers } & \multicolumn{3}{c}{ Teachers } \\
& A & $\mathbf{\%}$ & $\mathbf{D A}$ & $\mathbf{\%}$ & $\mathbf{A}$ & $\mathbf{\%}$ & DA & $\mathbf{\%}$ \\
\hline Orientation of new teaching staff & 28 & 70.0 & 12 & 30 & 10 & 12.5 & 70 & 87.5 \\
\hline Supervision of Curriculum time tabling & 27 & 67.5 & 13 & 32.5 & 30 & 37.5 & 50 & 62.5 \\
\hline In-service Training for teachers & 15 & 37.5 & 25 & 62.5 & 10 & 12.5 & 70 & 87.5 \\
\hline Checking of pupils' academic performance & 12 & 30.0 & 28 & 70.0 & 25 & 31.3 & 55 & 68.8 \\
\hline Organsing instructional materials for learning & 14 & 35.0 & 26 & 65.0 & 20 & 25.0 & 60 & 75.0 \\
\hline Source: Field data, 2020. & & & & & & & &
\end{tabular}


From Table 4, most of the head teachers, 28 representing $70 \%$ agreed they usually organize orientation for new teaching staff posted to their schools. While head teachers indicated organizing induction services regularly and sometimes, 70 representing $87.5 \%$ of the teacher who are beneficiary of the orientation disagreed that they never experienced the role at all. Most of the head teachers, 27 representing 37.5\% agreed that they always supervised curriculum time tabling. Majority of the teachers 50 representing 62.5\% rather disagreed that head teachers do supervise curriculum timetabling always and often, on the other hand $37.5 \%$ of the teachers agreed experiencing supervised curriculum timetabling. Regarding organization of in-service courses, 25 representing $62.5 \%$ of the head teachers disagreed of doing it and 15 representing 37.5\% of head teachers agreed of providing in-service courses. However, majority of the teachers, 70 representing $87.5 \%$ disagreed with head teachers 'provision of in- service training for teachers as it is expected to be practiced always and often. Majority of head teachers, 28 representing $70 \%$ and, 55 teachers representing $68.8 \%$ disagreed on monitoring of pupils' academic progress, only few of the head teachers 12 representing 30\% sometimes monitor the progress of pupils' academic progress by picking some exercise books to check exercises marked by the teachers. Most of the head teachers, 26 representing $65 \%$ and 60 representing $75 \%$ of teachers disagreed of the use of materials for classroom instructions by teachers always as pertained in some schools.

Research Question two: What are the pupils' views on their head teachers' supervisory roles in Jirapa Municipality of Ghana?

Table-5. Pupils' Views on their Head teachers' Supervisory duties.

\begin{tabular}{|c|c|c|c|c|c|c|c|c|c|c|}
\hline \multirow[t]{2}{*}{ Head teachers' Supervisory duties } & \multicolumn{2}{|c|}{ Always } & \multicolumn{2}{|c|}{ Often } & \multicolumn{2}{|c|}{ Some-times } & \multicolumn{2}{|c|}{ Rarely } & \multicolumn{2}{|c|}{ Never } \\
\hline & $\mathbf{F}$ & $\%$ & $\mathbf{F}$ & $\%$ & $\mathbf{F}$ & $\%$ & $\mathbf{F}$ & $\%$ & $\mathbf{F}$ & $\%$ \\
\hline Set target in terms of pupils' performance & $\mathrm{O}$ & $\mathrm{O}$ & 2 & 2.5 & 76 & 95 & 2 & 2.5 & $\mathrm{O}$ & $\mathrm{O}$ \\
\hline Ensuring organization of teaching time table & $\mathrm{O}$ & $\mathrm{O}$ & 4 & 5 & 70 & 87.5 & 2 & 2.5 & 4 & 5 \\
\hline $\begin{array}{l}\text { Providing teaching and learning resources to } \\
\text { use in teaching }\end{array}$ & $\mathrm{O}$ & $\mathrm{O}$ & 1 & 1.2 & 65 & 81.3 & 4 & 5 & 10 & 12.5 \\
\hline $\begin{array}{l}\text { Monitoring pupils academic } \\
\text { Progress }\end{array}$ & $\mathrm{O}$ & $\mathrm{O}$ & 1 & 1.2 & 7 & 8.8 & 4 & 5 & 68 & 85 \\
\hline $\begin{array}{l}\text { Head teachers always encourage teachers to } \\
\text { observe other teachers teach. }\end{array}$ & $\mathrm{O}$ & $\mathrm{O}$ & $\mathrm{O}$ & $\mathrm{O}$ & 4 & 5 & 75 & 93.8 & 1 & 1.2 \\
\hline $\begin{array}{l}\text { Conducting quiz competitions in Mathematics, } \\
\text { Science and English Language regularly to } \\
\text { ensure the completion of subject }\end{array}$ & $\mathrm{O}$ & $\mathrm{O}$ & $\mathrm{O}$ & $\mathrm{O}$ & 4 & 5 & 3 & 3.8 & 73 & 93.2 \\
\hline
\end{tabular}

\subsection{Pupils' Views on their Head teachers' Supervisory Roles}

Table 5 shows the pupils' perspectives on head teachers' roles in high schools in Jirapa Municipality. The study revealed that, 76 representing $95 \%$ of the pupils are of the view that their Head teachers' sometimes set performance targets for pupils, 2 representing $2.5 \%$ of the pupils rated as never being done while 2 representing $2.5 \%$ of the pupils also felt their head teachers often and rarely indicate targets to be attained in terms of teacher performance. The study disclosed that majority of the pupils, 70 representing $87.5 \%$ expressed concerns about teaching with insistence on the preparation of time table sometimes with 4 representing $5 \%$ experienced often and also 4 representing $5 \%$ of the pupils had never experienced the role. On the aspect of providing teaching and learning resources, 65 representing $81.3 \%$ of the pupils rated that their head teacher sometimes do it, while 10 representing $12.5 \%$ of the pupils reported that they never experienced head teacher providing teaching and learning resources. Also 7 out of the number of pupils representing $8.8 \%$ reported that their head teachers sometimes monitor their academic progress. However, 68 representing $85 \%$ greater number of pupil respondents felt their Head teachers' never monitor their academic progress while 4 representing $5 \%$ reported that their head teacher often perform this 
role. Comparatively a significant number 75 representing $93.8 \%$ of the pupils pointed out that Head teachers' rarely support teachers in helping others to teach and this registered the highest rating. Only 4 representing $5 \%$ of the pupils indicated their head teachers sometimes encourage teachers to sit in other teachers' classroom to observe their colleagues teach while 1 representing $1.2 \%$ of the pupils felt their Head teachers scarcely offered support to teachers to assist others to teach. Regarding the issue of whether head teachers always encourage their teachers to conduct quiz competitions in Mathematics, Science and English Language regularly to ensure the completion of subject, 73 representing $93.2 \%$ of the pupils rated that they never experienced such thing in their schools, while 4 representing $5 \%$ of the pupils rated that they sometimes experienced quiz competitions in Mathematics, Science and English Language regularly to ensure the completion of subject and 3 representing $3.8 \%$ of the pupils rated they rarely experienced it in their schools.

In the qualitative data, the study considered this question, what are some of the supervisory roles you perform in your school to promote academic performance? Some of the head teachers remarked as follows;

3.2. Supervisory Roles Performed in the Schools

Htr. 1

Well, as part of my supervisory roles, I am to ensure that teachers teach. I am to ensure that teachers prepare adequate lesson notes. I sometimes buy TLMs for teachers to teach when we have access to the small capitation grant that comes. I also observe teachers teach but not always. And I sometimes also encourage pupils to learn hard. (Interview Data, 2020).

This finding is in line with Kerubo (2010) who insinuates that most head teachers have limited knowledge of their responsibilities as instructional supervisors, all they know is preparation of time table and records of instructional activities. However, according to him, other roles such as personal guidance by head teachers which involves design of time table, lesson plans and visit to schools are least addressed. What is conspicuously absent in Kerubo (2010) findings is how these activities impact on the student's academic progress.

Htr. 4

Eeeei, my supervisory roles are many but I do not have ample time to do all as expected. What I sometimes do is to vet teachers lesson notes (Interview Data, 2020).

This finding concurs with the finding of Kruskamp (2003), who found that constraints to instructional supervision do exist. He further indicated that the major obstacle to instructional supervision experienced is the lack of time, or the number of other tasks that fall under her responsibility. Other constraints to instructional supervision are the lack of local school emphasis on department chairs acting as instructional supervisors, the resistance to supervision by veteran teachers, and the challenges presented by increased stress on teachers $\|$ due to the accountability of high-stakes testing.

\subsection{Induction Service for Teachers}

\section{Htr. 10.}

As for me Jerry, I must be honest. I do not understand in details what this induction is all about. I do not know how to carry it out in my school. I only assign the subject to the new teachers and give them the lesson note book (Interview Data, 2020).

This finding supports Madziyire (2013), who contends that many schools lack teachers with the requisite experience and training in supervisory roles. 


\subsection{Frequency of Supervisory Roles}

How often do you carry out some of these supervisory roles as head teacher to help promote academic performance in the school?

\section{Htr 7.}

It is supposed to be often, some kind of routine thing but where will you get the time to be doing these things my brother? To the best of your knowledge, do you conduct induction to new teachers as part of your supervisory roles?

This finding concurs with the finding of Kruskamp (2003), who pointed shortcomings to instructional supervision as lack of orientation, seminars or in-service training offered teachers as well as lack of time and cooperation of the school staff.

From the discussions, the key findings are; most of the head teachers and teachers do not agree that they always organise an orientation for the newly appointed teachers, regularly check time-table and assess academic performance of students. However, the study revealed that teachers were entitled to refresher courses and inservice-training to be organized for them from time to time to assist them in their duties and functions but this was poorly rated. In the findings, it has emerged that setting performance target for pupils and teaches' were not always done. Also ensuring organization of teaching time table as well as Head teachers always encouraging other teachers to observe others teach was rarely done. Conducting quiz competitions in Mathematics, Science and English Language regularly to ensure healthy competition among pupils and the completion of subjects in the term was not encouraging. The pupils' observation showed that head teachers do not generally perform instructional supervisory roles as expected.

\section{CONCLUSIONS}

Head teachers do not always carry out their supervisory roles as expected in the Municipality and this may be one of the reasons why there is poor performance in the academic performance of pupils in the Municipality. Also, the Municipality has not put in place measures to enable regular professional training of head teachers in the act of supervision, monitoring and evaluation of schools making them ineffective in carrying out their supervisory role. In-service training/ workshops are not regularly organized to upgrade the professional competences of head teachers and teachers. Detachment of head teaches and making them concentrate solely on their supervisory role will be a motivational factor for most of them to be very effective and efficient, hence, improving good academic performance in the schools.

\section{RECOMMENDATIONS}

1. The decentralized system of education delivery in Ghana assumes an important role for head teachers to collaborate with teachers and communities in school policy formation (Ghana Education Service, 2001). In the light of this, this study raises the need for a policy to make it compulsory for all heads to go through extensive leadership training before taking up any headship role, The GES should regularly organize workshops, seminars and in-service trainings on supervisory roles of head teachers and assistant head teachers to enable them to up-date their knowledge and skills on school supervision. This will make teachers very competent and innovative in their teaching career.

2. As part of dealing with relational aspects in teacher involvement, efforts must be made to change teacher attitudes, beliefs and behaviours. This study calls for all educational institutions especially Colleges of Education and the Universities to help train head teachers and teachers to be aware of their roles as school 
instructional supervisors. This will assist them to give of their best in their instructional supervisory role in their areas of practice

3. The study shows that it is possible to foster collaboration between head teachers and teachers through effective design of school time tabling. This implies that heads of schools and other supervisors should redesign schools` time tables to suit the use of instructional time in their lessons. All the necessary resources must be provided for school heads to adequately discharge this important role. When this is done, teachers can be effectively monitored in teaching and learning.

\section{REFERENCES}

Adu, E. (2019). Internal and External supervision: Issue, challenges and way forward. International Journal Educational Science, $8(3), 71-75$.

Akinola, W. (2010). WAEC: Who to blame for pupils poor performance? Nigerian compass.

Ayeni, H., Adeolu, F., \& Joshua, A. (2012). Teachers instructional task performance and quality assurance of pupils learning outcomes in Nigerian secondary schools. International Journal of Research Studies, 1(1), 33-42. Available at: https://doi.org/10.5861/ijrset.2012.v1i1.47.

Beach, D. B., \& Reinhartz, J. (2000). Supervisory leadership: Focus on instruction. Toronto: Allyn and Bacon.

Bertalanffy, L. (2015). General system theory. Foundations, development, applications. With a Foreword by Wolfgang Hofkirchner and David Rousseau. Braziller.

Blase, R., \& Blasé, A. (2004). Handbook of instructional leadership. How really good principals promote teaching and learning (2nd ed.). Thousand Oaks: Corwin Press.

Boyd, C. O. (2001). Phenomenology the method: Nursing research on quantitative perspective. Sudbury: Jones Publishers.

Cohen, L., Manion, L., \& Morrison, K. (2017). Research methods in education (8th ed.). London: Routledge

Creswell, J. W. (2014). Research design: Qualitative, quantitative and mixed method approaches. Thousand Oaks, California: Sage Publications.

Creswell, J. W., \& Plano, C. (2011). Designing and conducting mixed method research (2nd ed.). Thousand Oaks, CA: Sage Publications.

De Grauwe, A. (2007). Transforming school supervision into a tool for quality improvement. International Review of Education/Internationale Zeitschrift für Erziehungswissenschaft/Revue Internationale de l'Education, 53(5/6), 709-714. Available at: https://doi.org/10.1007/s11159-007-9057-9.

Esia-Donkor, K. (2014). Attaining school and educational goals: Duties of head teachers of public basic schools in Ghana. Journal of Education and Practice, 5(1), 64-72.

Esia-Donkor, K., \& Baffoe, S. (2018). Instructional supervisory practices of head teachers and teacher motivation in public basic schools. Journal of Education and e-learning Research, 5(1), 43-50.

Fischer, C. F. (2011). Supervision of instruction. London: Falmer Press.

Fullan, M. (2014). The principal three keys to maximising impact. San Fransisco, CA: Jossey Press.

Gelman, A., \& Hill. (2007). Data analysis using regression and multilevel/Hierachical models. New York: Cambridge University Press.

Ghana Education Service. (2001). SMC/PTA handbook: Improving quality education through community participation. Accra: Ghana Publishing Ltd.

Glanz, J., \& Heinmann, R. (2018). Encouraging reflective practice in educational supervision through action research and appreciative inquiry. In S. Zepeda E J. Ponticell (Eds.), The wiley handbook of educational supervision. New York: Wiley Blackwell.

Glenn, A. B. (2012). Document analysis as a qualitative research method. Qualitative Research Journal, 9(2), 27-40. 
Glickman, C. (2010). A place called school. New York: MCGraw-Hill.

Glickman, C. D., Gordon, S. P., \& Ross-Gordon, M. (2001). Supervision and instructional leadership. (7th ed.). Needman Heights, MA: Allyn \& Bacon.

Hallinger, P., \& Heck, P. (2018). Collaborative leadership and school improvement: Understanding the impact on school capacity and student learning. School Leadership and Management, 30(2), 95- 110.

Jenkins, C. (2009). Teachers under pressure: Stress in the teaching profession. London: Routledge.

Kerubo, M. J. (2010). Role of head teachers' instructional supervision on Kenya certificate of primary education performance in public primary schools. Kenya: Dagoretti District.

Kruskamp, F. (2003). Instructional supervision and the role of high school department chairs. Doctor of Education Dissertation, Athens :University of Georgia.

Kusi, H., \& Mensah, D. D. (2014). Head teacher supervisory styles: Key issues to consider in teacher motivation. Journal of Education of and Teching, 13(1), 149-157.

Leithwood, K., Jantzi, D., \& Lee, K. (2004). Transformational leadership: How head teachers can help reform school cultures. School Effectiveness and School Improvement, 1(4), 249-280. Available at: https://doi.org/10.1080/0924345900010402.

Lincoln, Y. S., \& Guba, E. G. (2015). Naturalistic inquiry. London: Sage Publication.

Madziyire, N. C. (2013). Educational leadership and supervision. Harare: University of Zimbabwe.

Marks, J. R. (2008). Handbook of educational supervision. Boston: Allyn and Bacon Inc.

Morse, J. (1994). Approach to qualitative-quantitative methodological triangulation. Nursing Research, 40(1), $120-123$.

Nakpodia, E. D. (2006). Educational administration: A new approach (2nd ed., pp. 181-215). Warri: Jonokase Publishers.

Nolan, J. J., \& Hoover, L. A. (2008). Teacher supervision and evaluation: THeory into practice (2nd ed.). New York: John Willey \& Sons.

Okendu, J. N. (2012). The influence of instructional process and supervision on academic performance of secondary school students of rivers state, Nigeria. Academic Research International Journal, 3(1), 147-151.

Palandra, J. (2010). Teaching staff development in Asia. New York: McGraw-Hill Companies Inc.

Planturrroot, S. (2006). Psychological theory on supervision. New York: Braziller.

Sapsford, C. (2007). Supervisory styles in bulilimangwe district. Harare: University of Zimbabwe.

Sergiovanni, T. J., Starratt, R. J., \& Sullivan, T. J. (2011). Should supervision be abolished: A redefinition (4th ed.). Boston: McGrawHill.

Sharma, S., Yusoff, M., Kannan, S., \& Baba, S. B. (2011). Concerns of teachers and principals on instructional supervision in three Asian countries. International Journal of Social Science and Humanity, 1(3), $214-217$. Available at: https://doi.org/10.7763/ijssh.2011.v1.37.

Yousuf, M. I. (2011). Concept of supervision and supervisory practices at primary level in Pakistan. International Educational Studies, 4(4), 28-35.

Zedepeda, S. J. (2012). Making sense of the principal's work. New Jersey: Prentice Hall.

Zepeda, S. (2003). The principal as instructional leader, a handbook for supervisors. Larchmount, NY: Eye on Education.

Online Science Publishing is not responsible or answerable for any loss, damage or liability, etc. caused in relation to/arising out of the use of the content. Any queries should be directed to the corresponding author of the article. 